\title{
"Nothing in Particular": Queer Theory and the Loss of the Social
}

\section{ANDREW LESK}

Andrew Lesk recently completed his dissertation, The Play of Desire: Sinclair Ross's Gay Fiction, at the Université de Montréal. He has published on Ross, Leonard Cohen, John Glassco, Jack Hodgins, Willa Cather, Chinua Achebe, Shyam Selvadurai, and Rider Haggard, in addition to articles on culture and film. He is an instructor at Centennial College in Toronto.

厂

$\mathrm{n}$ his genealogical analysis of male homosexualities, David Halperin summarily argues that "what homosexuality signifies today is an effect of [a] cumulative process of historical overlay and accretion" (91). Halperin proceeds from this justifiable and modern concept of homosexuality since it "defines the horizons of our immediate understanding and inevitably shapes our inquiries into same-sex sexual desire and behavior in the past" (90). Perhaps it seems obvious that no matter where gays and lesbians have come from, we have invariably ended up at today. Having thus arrived with all kinds of baggage, our cumulative understandings of (homo)sexual desire invariably cast long shadows, over the past and into the future. This is what Halperin describes as an inevitable "conceptual tyranny" (90), one that might be ameliorated if we let go of modern perceptions when we stare into our histories.

Yet where I become stuck is Halperin's implicit notion of our apparent 'arrival' and what that might mean in different contexts. Halperin is likely just positioning a foundational beginning for historical analysis. But I'm more interested in this literal and figurative point as it might suggest a historical end. Certainly, in many recent queer critiques of homosexual identity (whether historical, political, or social), much has been made of the current assimilation 
of lesbians and gays into the mainstream: the increasing acquisition of legal rights; the attempts to marry; and the frequent appearances on primetime American sitcoms, such as Will \& Grace, to name but a few. What happened to the radical sexual liberation that the struggle for lesbian and gay equality was initially about?

When I gave a version of this paper in Montreal in 1998, at Concordia University's "Sex on the Edge Conference," I did not anticipate some of the antagonism my talk subsequently engendered. After a number of questions, it became clear that the disagreement with my critique of queer theory arose from a primary source: namely, certain queer activists whose distinction between 'queer' and 'gay and lesbian' was both theoretically discrete and served as a judgment that influenced their daily living. Now, as then, these self-differentiating queers look upon gays and lesbians as conforming and as having abandoned their dissenting activist roots in favor of the 'trappings' that flow from their adaptation of (chiefly white) economically middle-class identities. But what are these apparent trimmings and frills to which gays and lesbians have given themselves?

I had prefaced my Montréal paper with a description of the 1993 murder of a young Texas man, Nicholas West, ${ }^{2}$ in order to make a point, as I again do here, about certain presumptions of queer theory and activism. Queer theory at once maintains that gays and lesbians have finally 'arrived' and that their time has passed. It can afford such presumptions only because it suffers from a profound and severe disconnect from the varied, lived existences of self-identified homosexuals. I argue that queer anti-identity constructions imperil essential communal identification and political responsiveness, and offer instead individual self-centered agendas incapable of political engagement. Moreover, and more dangerously, this queer threat carries with it the implicit presumption of an eventual takeover and effacement of the historical locations of homosexuals, lived or

1 "The 'Diseased' Homo: Queer Theory and the Re-inscription of Homophobia," Sex on the Edge Conference, Concordia University, Montreal, 9 Oct. 1998. Here, I embraced the notion that gays and lesbians still have not 'arrived' as full, unfettered citizens with complete human rights.

${ }^{2}$ On the night of 30 Nov. 1993, West was kidnapped, beaten, made to strip, and repeatedly shot. His death became part of the 1997 documentary about hate crimes, Licensed to Kill (dir. Dong). 
literary. As Robert K. Martin forcefully reminded the audience at the Montréal conference's closing plenary, the study of lesbian and gay history is not done. Likewise, we are not done with reimagining and reforming homosexual identifications and affiliations, problematic as they may be, because we have not 'arrived.'

After describing West's murder, I then offered but one of many queer oppositional alternatives to the supposed gay and lesbian mainstream: a 1991 editorial from the zine вімвох, by the pseudonymous Johnny Noxema and Rex Boy.

You are entering a gay and lesbian free zone ... Effective immediately, BIмвох is at war against lesbians and gays. A war in which modern queer boys and queer girls are united against the prehistoric thinking and demented self-serving politics of the above-mentioned scum. вімвоx hereby renounces its past use of the term lesbian and/or gay in a positive manner. This is a civil war against the ultimate evil, and consequently we must identify us and them in no uncertain terms ... So, dear lesbian womon [sic] or gay man to whom perhaps Biмвox has been inappropriately posted ... prepare to pay dearly for the way you and your kind have fucked things up. (Qtd. in Cooper 31) ${ }^{3}$

The reader of this rant may either laugh and dismiss the overwhelming violence of the editorial as an example of the extreme irony embraced by the queer movement, or be taken aback by the naïveté of people who, using such shock politics, underestimate the fact that violence that includes anything from literary gay-bashing to physical harm is never ironic.

This now somewhat dated exposition, from a self-identified antiassimilationist movement, is not necessarily concomitant with queer theory, nor is its location in my discussion meant to imply that this is theory in practice. Yet the attack on a materialistic, commodified class of homosexuals is clear in its antinormative performativity. BIMBOX, given over to such textual irony, shares with its academic counterpart in queer theory a desire to displace a socially ingrained but supposedly outdated identity binarism: heterosexual/homosexual.

\footnotetext{
${ }^{3}$ My discussion is indebted in part to Donald Morton's analysis of the editorial, in his essay "Changing the Terms."
} 


\section{"Nothing in particular"}

I regard the difference between the two - queer activism and theory - slender and ultimately unimportant. Whereas queer activists use their sexual selves and social spaces as sites or conduits for political intervention, queer theorists use homosexual transgression but discard homosexual identity in favor of a politically disinterested program marked by a deeply troubling deconstructive rhetoric. In responding to similar charges of queer political imprudence, Diana Fuss writes somewhat antagonistically that "politics is deployed as the final measuring stick for assessing the present utility, and thus the final relevance, of theories of gay identity" (106); and Judith Butler, finetuning that sentiment, asserts that "the deconstruction of identity is not the deconstruction of politics; rather, it establishes as political the very terms through which identity is articulated" (Gender Trouble 148). It is the strangest of dances that they propose: a wary waltz into the domains of political expression stripped of any selfidentifying politics. To identify as "gay" or "lesbian" is deconstructed by Fuss and Butler only to the extent that people understand that such identification is a shameful engagement, as if gays and lesbians are not astute enough to be conscious of the pitfalls of identity politics.

One cannot, at this time, completely assess the political efficacy of queer theory's aims of resistance to Michael Warner's "regimes of the normal" (Fear xxvi), for it is difficult to see how transgressive diffusions of identity can in any way present an immediate challenge to capitalist heteronormativity and socioeconomic inequities. After all, queer recompense seems to be an update of the Socratic credo that the nondeconstructed identity and the communal action predicated by social cross-identification is not worth having. In any case, the irony of queer's activist pragmatics and academic theoretics is that political efficacy is the opposite of both - as the demise of Queer Nation has already shown. BIMBox's editorial, as ironic textual activism, highlights in many ways the slippage between the two groups, especially as they both abandon the material homosexual subject in favor of an antihomosexual and anti-identitarian agency.

The hard-won gains made by the gay and lesbian movements are now in danger of being surpassed by a vague, and supposedly more agreeable, 'gender/sexuality' agenda that, for me, evokes 
suspicion, for it lends itself to a definitional ambiguity even greater than the one found in the word "queer." William B. Turner, in characterizing queer, is typical in his approval of such definitional indistinction; he contends that

'Queer' has the virtue of offering, in the context of academic inquiry into gender identity and sexual identity, a relatively novel term that connotes etymologically a crossing of boundaries but that refers to nothing in particular, thus leaving the question of its denotations open to contest and revision. (35)

This proposal of "nothing in particular" is all the more discomforting in that Turner appears sincerely to believe that offering up "nothing" as a template by which to argue for a social politics of progression or activism will somehow bypass the rapacious interests of more conservative movements. The conservative nature of queer (anti-) identity means, as Max $\mathrm{H}$. Kirsch argues, that the ambiguity of a queer politics, in allowing itself to be usurped by conservative forces, "represents an opposition that does not oppose. It includes the spectrum of ideologies from left to right, with the caveat that the theory generated around it is primarily neo-conservative, suggesting that the organizing of collective action is all but impossible" (99). Thus, Turner's mystifying pronouncement also highlights how queer has little to offer other than an oppositional ideology whose main tenet is constant contestation.

Turner's posture strikes me as indicative of an ongoing shift in recent Western academic circles to promote sexuality/gender studies that do not take into account, at the forefront, historically specific homosexual identities. Instead, the adoption of queer merely favors what can only be an ironically conservative move to efface any effort to self-identify homosexually. And it is the fear both of identity or being identified by way of one's (homo)sexuality - and of the seemingly more inclusive-sounding queer that have provided much of the impetus.

Eric Savoy, in his critique of things queer, cautions that "to theorize homosexuality as an epistemological crisis not susceptible to resolution is, if not to elide the 'gay man,' at least to shift academic attention away from that affirmative [gay studies] position" (138). Hence, homosexuals, the study of them, and their studies, risk being passed by in favor of an adoption of indistinct queerness, whose 
epistemological foundation is built primarily on not being seen as lesbian or gay. The resultant invisibility of the lesbian or gay subject is both figurative and literal.

My assertions that queer anti-identity formations threaten gay and lesbian communal identification and political responsiveness are certainly not new, although I believe they retain a strong sense of urgency. Exemplary of queer critiques is David Van Leer's 1989 reproof of Eve Kosofsky Sedgwick's political inutility and (what he sees as) her underwriting a homophobic thematics (Van Leer 605). However, I do not wish merely to repeat Van Leer's line of inquiry. Rather, I shall survey and examine the ways in which much recent queer theory, in its nonadmitted drive for an ideal and deconstructed subject-outside-all-subjects, effectively lops off its dis-eased progenitor, the socially self-characterized homosexual, a subject ostensibly either unable or unwilling to transform her or his binarized and essentialist-based identity.

Despite the demise of groups such as Queer Nation and the relative silence of queer social activism, queer theorizing continues, though it has become ever more detached from the activism that once inspired much of its formative drive. Queer Nation's practices, which eschewed homosexual identity in praise of a generalized difference, are more than just superficially similar to the theorists who have embraced such calls to difference. On the one hand, Savoy emphasizes that Queer Nation's commitment to concise activism differs from theoretical queerness's "highly suspect appropriation of 'queerness' in challenging the very concept of 'identity' and in dismantling the cohesiveness that accrues at the site of the lesbian and the gay." Savoy's point concisely highlights the difference "between queer irony and irony's queerness, between the rhetoric of politics and deconstructive rhetoric" (142). On the other hand, it seems inevitable (especially considering the demise of Queer Nation) that a politics based on irony could only wear out its welcome - as with any practice that breeds familiarity - as its ability to create change wanes. Queer Nation's organizational tactics, such as the promotion of the free rein of all desire(s), are part of the unworkability of queer theory in the social realm.

Likewise, queer theory suffers from an awkward relation to the social. Its basic premise of atomized difference and valorized individualism proposes that all meanings - across cultures, sex, 
gender, race - have the possibility of becoming enacted at any time and in any place. This is simply impossible. A structure that would allow all options to exist simultaneously, so that all people could have access to, and possible fulfilment of, any personal choice, cannot exist. Such structures would involve immediate self-contradiction and give way to chaos. In the case of the failure of Queer Nation, the irrationality of this wished-for structure was overlooked, and the organization's demise was seen as the simple inability of different members to get along.

Queer deconstructive rhetoric, especially as it permeates the political body, will invariably give way to the same self-destruction that Queer Nation faced, because such theory has a direct investment in getting rid of material evidence, which is to say, the homosexual body.

Queer Nation's miming of civil rights sit-ins failed to reclaim public space precisely because queer visibility, in its use of (homo)sexual transgression, failed to keep up a day-to-day reinforcement of its project; the Queer Nation members were defeated by their own provisionality. Queer theorists presuppose a similar impermanence - much like Turner's "nothing in particular" - in tacitly intimating that the ongoing stimuli and the perpetual selfcritique demanded can somehow be maintained over time. Queer theory's naive view is that it is possible to resist heteronormative regimes whose investments in the status quo are prohibitively fierce, especially in these days of capitalistic globalism.

In constructing this resistance, the main anti-identitarian tenets of the work of many queer theorists (including especially Judith Butler, Diana Fuss, Eve Sedgwick, and Michael Warner) disavow homosexual identity and propose instead that everyone is presumably or potentially queer. Although they reduce homosexual identity to a trope of transgression, they nevertheless rely on this mutinous category for its social and libidinal noncompliance; it is required and concomitantly refused. Instead of activism involving material bodies, however, what is proffered is activism by way of deconstructive rhetoric and signification. Sedgwick states, when writing of Foucault's questioning of regulatory sexuality, that "future interrogations of normative heterosexuality ... must begin from, and perhaps return to, the definitional centers of the achieved and loved 'perversion.' It must also begin from gay and lesbian studies" 
("Gender Criticism" 292). Despite her fruitful examination of the arbitrary nature of the ordering of sexuality and an apparent valorizing of gay and lesbian studies, Sedgwick's 'beginning' would spell the end of lesbian and gay studies, and her 'return' to this arena is merely an opportunity to scavenge the graveyard of gay and lesbian identity for the rudiments useful for constructing, in Frankenstein fashion, a new queer corpus.

Sedgwick and her followers suggest that if we can change the terms of the argument to establish a new way to think about libidinal matters, we might thereby be able to regulate the rhetoric of sexuality. Since sex is text, or at least an effect of textual discourse, and all text is rhetorical in its ability to signify, a queer governance can change the heterosexist social apparatuses that oppress and dominate. But, as Donald Morton states, when writing of the privileged status of textuality accorded by the queer, "from the queer theory perspective, gayness is nothing more than a mirage of signification - a gay-effect" ("Changing" 12).

If homosexuals are part of a normative order signaled by the heterosexual/homosexual binary, it is curious that the queer theorists do not call upon the (supposedly) more powerful member of the binary, the heterosexual. It may seem axiomatic that to hail the hetero position would result in the reinscription of the dominant regime, since there is nothing contesting or resisting about heterosexuality. It may seem obvious, but it needs restating: heterosexuals are in no way about to relinquish their privilege. As Tom Warner wryly notes, "There seems to be little evidence to suggest that there is any reluctance to be labelled a heterosexual" (265). I contend, how can queer theorists simply appropriate only what is transgressive about the homosexual if this category has now become subsumed by and part of Michael Warner's "regimes of the normal"? Has such transgression not already been influenced or appropriated by the dominant group?

These unexamined assumptions result in the blaming of homosexuals for their own positioning in the social framework. The irony is that the queer position deftly merges with a reactionary conservative one. When queer BIMBOx attacks homosexuals as having been complicit in their own ruin, there remains amid the rubble of their irony a residual suspicion that homosexuals, possessing coherent, rational identities, have been collaborators in maintaining 
a status quo society. ${ }^{4}$ While one might look upon BIMBox's musings as entirely ironic in their efforts to shake up complacent gays and lesbians, the subterfuge elicits quite a literal reinscription of homophobia. When Cooper asserts that Noxema and Rex Boy "pose questions about identity that are as lushly poetic as they are superficially irresponsible" and that "to become engaged in their illogic is to sense the idiocy that goes hand in hand with delusions of a united front" (31), he suggests that the textual ironizing of a supposedly coherent and united homosexual subject is required to make these queer writers' point. Therefore, attacking homosexuals cannot cause harm because homosexual material existence has been transformed into an allegory and is thus not the 'real thing.' Gays, as signified beings within the queer textual world, are simply, as Morton states, "gay-effects." They have lost a sense of material being and, despite Judith Butler's remonstrance (in Bodies That Matter), they are bodies that do not matter. To use this queer textual logic, Nicholas West died because of faulty identification as a gay man; but if he had not been an out gay man, his death would probably not have occurred.

BIMBOX's use of violence as critique cannot help but recall the real material lives of gay men and lesbians who have suffered, today and in history. ${ }^{5}$ The editorial writers might protest that they, though queer, are interested in same-sex sex. ${ }^{6}$ Yet at this juncture, where practice violently combines with a theory of emancipation, the resulting discourse cancels out the homosexual subject. Rising phoenixlike from the ashes of this infernal collision is the unscathed

${ }^{4}$ The verve of much, but by no means all, recent gay and lesbian activism has been assimilationist. Tom Warner deftly summarizes the queer critique: "Rights advocacy and promotion of identity, perhaps inevitably, become conservative influences that eventually impede and then outrightly resist the more radical objectives of liberation and sexual freedom. A synergy of rights attainment and identities that are respectable and non-threatening to the heterosexual mainstream takes hold, and becomes itself constraining and oppressive, marginalizing those who do not, or refuse to, conform" (263).

${ }^{5}$ I do not suggest than the litmus test of lesbian and gay identity and existence should be suffering, although it is important to remind ourselves of historical fact.

${ }^{6}$ Even this is debatable. Johnny Noxema, in his interview with Cooper, says (ironically?) that "For my friends and myself, sex is the last thing on our minds" (32). 
heterosexual who can blame homosexual deviance as the cause of unrest. When interviewed by Cooper, Noxema, in his rally against gays, notes that Jeffrey Dahmer picked up one of his victims at a gay pride parade. This is, no doubt, seen as ironic by Noxema; nonetheless, his joking implies that both perpetrator and victim deserve one another, that if it had not been for their identification as gay no violence would have occurred. Not only is violence against and/or by homosexuals positioned as innately homosexual, but it is thematized as such within the theoretical understanding that homosexuals have caused their own (violent) displacement by dint of their faulty essentialized nature.

\section{Why Fear a Queer Planet?}

Given the ongoing struggles of homosexuals - including the effort to stay alive - I find it strange that queer theorist Michael Warner remarks, when addressing the admirable accomplishments of gays and lesbians, that "the success of that work now makes some other kinds of thinking necessary" (Fear $\mathrm{x}$ ). This is invariably the kind of statement made by those who are privileged enough not to have to worry about random violence, the effects of racism, sexism, and, especially, class. Warner's enveloping of gay and lesbian history within a theoretical dynamic is not surprising considering that in order for queer theory to take over, it must dispense with the homosexual body and the politics attendant upon such material existence, and at the same time spirit away the representation of the homosexual required for transgressive practices. Warner's assertion of a dubious "success" neatly allows him to remark upon (and appropriate) what has perhaps been a success - more queer academics? - and leave the scraps of essentialism around for queers like Cooper to pick up, recycle, and demonize once more.

For queer practice, according to Michael Warner, there remains the nonmedical, nonradical, and nonphysical issues of "challeng[ing] the common understanding of what gender difference means, or what the state is for, or what 'health' entails, or what would define fairness, or what a good relation to the planet's environment would be" (Fear xiii). But he elides the idea that similar practices were once vaunted by the radical gay left in the early 1970s. Warner shifts the issue from efficacy to 'difference' - not differences between people but differences within the self that reveal the constructed, contingent, 
and ambiguous nature of identity. One might gather from this that homosexuals possess a hazardous, binarized essence that universalizes the notion of difference, whereas queers, in disrupting essentialism, do "a kind of practical social reflection just in finding ways of being queer" (Fear xiii).

This kind of navel-gazing reveals that Warner's project encourages a self-concerned individualism and is, in fact, antisocial. Again advocating the possibility of a queer entity possessing all the expressive punch of 'have-a-nice-day' sentiments, Warner's 2002 book describes the queer world as "a space of entrances, exits, unsystematized lines of acquaintance, projected horizons, typifying examples, alternate routes, blockages, incommensurate geographies" (Publics 198). But what exactly does this mean? Again, Turner's "nothing in particular" provides a fitting response. Yet Warner's watery rhetoric does serve a purpose: it underscores a projected and hoped-for unfettered individualism disconnected from the social and unable to form a radical or emancipatory politics of any sort. Warner asserts that queer politics invokes "norms of liberal modernity such as self-determination and self-representation ... [and] it continues to value sexuality by linking it to the expressive capacities of individuals"; and he resolutely determines that queer theory "relies absolutely on norms of expressive individualism and an understanding of sexuality in terms of those norms" (Publics 219).

That people operate, generally, from the locus of self is undeniable. But they also act communally in order to further their own interests, especially those they may share with others. Although Michael Warner's queers might be able to promote radical notions of sexuality, it cannot be that they could do so together, a basic requirement of political action. Lost as they are while exploring those "projected horizons" of the queer world, Warner's fellow pilgrims are also lost to each other since their lines of acquaintance are unsystematized. How would they recognize not only each other but what each other believes has to be done?

It is telling that Warner contradicts himself by stating that "queer politics is anti-assimilationist, non-individualist, and mobilizes noncommunitarian practices of public-sphere media" (Publics 221). Perhaps Warner means that such politics are nonindividualist simply because there cannot be anything political organized on a queer planet. Warner's queer theory, while getting on with the serious work 
of deconstructive understandings of the nonmaterial world, evokes an ever inward-looking world of atomized persons finding ways to be more themselves, the ultimate identity. Kirsch calls this the "II matter most' philosophy in which individualism, subversion, and social resistance are equated. This conjoining of complex issues is encouraged by a culture that is now more than ever oriented towards separating the individual from the social, promoting an ideal that we are all unique, special, unfettered by structural forces outside our control" (3). From Warner's perspective, there is no continuity between people as libidinal localities are prioritized; each person, in becoming his or her own unique 'moment in history,' nurtures a passion for the self that supersedes communal action or political interests.

For Warner, "queer sexuality is like gender or race in being a political form of embodiment that is defined as noise or interference in the disembodying frame of citizenship" (Fear xix-xx). This is a significant point, but here, the embodied queer person is progressive only insofar as he or she disturbs; to what (political) end is not known since queers disdain a strictly goal-oriented politics, especially since such prescriptions tend to play into the predetermining hegemony of a coherent, stable, heteronormative ideology. The main tenet of "practical social reflection," defined by Warner, is "the project of elaborating, in ways that cannot be predicted in advance, this question: What do queers want?" (Fear vii). This view, shared by other queer theorists (Butler, Bodies 229; Gender Trouble 7; Fuss 106; Sedgwick, Epistemology 12), underscores a disinterested risk politics that is commensurate with abandoning essentialized collectivities.

Outdated lesbian and gay collective political action, Michael Warner elaborates, reinforces the regulatory framework of binarized structures since, he implies, the homosexual is part of "normalcy." Warner asserts that the queer is "an aggressive impulse of generalization; it rejects a minoritizing logic of toleration or simple political interest representation in favor of a more thorough resistance to regimes of the normal" (Fear xxvi). But I find that the idea that the homosexual subject has suddenly shifted from the margins into the centrality implied by "normal" would likely be startling (though for opposing reasons) to a large number of heterosexuals and homosexuals alike. Such queer resistance, fighting for necessarily 
unanticipated effects, ultimately leaves itself open to appropriation by normative ideological structures, since it is these structures that will co-opt unregulated activity. Resistance by directionless atomized entities is not enough.

Neither is opposition in the form of "tempered rage and carnivalesque display" (Fear xvii). These methods of social release do little to transgress the temper of society, though Warner is quick to add that it is the normalizing feature of society that also must be resisted. Resistance in itself, however, as a critique or a call to action, implies direction; Warner omits - notwithstanding his push for a nonteleological project - that every argument produces its own dominance and will carry with it ideological implications. Warner believes that queers can become ideology-free (or at least free of dominant ideologies) through rigorous resistance that would never allow any ideology to settle.

But queering's appeal to constant contestation and disturbance will only become its own ideology: the ideology of change. Warner, seeing change as perpetual motion, confuses his apparent favoring of the choice of embracing all random directions with the simple ability to choose; the latter signals direction, even when the choice is resistance, whereas the former implies the impossibility that all directions can function within a structure at the same time. Of these queer attempts to subvert identity, Stephen Seidman writes that in queer theory there is "a celebration of liminality, of the spaces between or outside structure, a kind of anarchistic championing of 'pure' freedom from all constraints and limits" ("Identity" 133). It appears queer theory courts anarchy or chaos, only it becomes disguised by "risking the incoherence of identity" (Butler, Bodies 113).

Sounding much like Michael Warner, Judith Butler too sees queerness as a sort of disrupting, disembodied agency whose only force is a constant redeployment against (rationally coherent) identity. She maintains that identities produce exclusions and abjections and therefore fail to make connections across the very differences that are needed to (re)democratize coalitional frames. This 'new democracy' entails a rejection of the essentialized homosexual subject who is part of what Butler calls the "socially instituted and maintained norms of intelligibility" (Gender Trouble 16-17). Emphasizing the specific and the local throughout her work, she advocates "the possibility of agency and transformation" (Gender 
Trouble 7) but, as Seidman notes ("Deconstructing" 137), she never describes the inherent possibilities entailed by her project's destination.

Butler, not surprisingly, appears to backtrack somewhat from a thorough constructivist position by suggesting a kind of essentialism that would, she states, "affirm identities that are alternately instituted and relinquished according to the purposes at hand; [the open coalition] will be an open assemblage that permits of multiple convergences and divergences without obedience to a normative telos of definitional closure" (Gender Trouble 16). This ploy of strategic essentialism, found elsewhere among queer theorists (Edelman xvi; Fuss 105), allows for identity with the assurance that such strategies are required to tap the transgression afforded by homosexual subjectivity. But if queer theory, as Savoy says, "locates homosexuality in suspension or liminality, and thus suspends the coherence of identity politics" (137), how can an invisible subject continue to underwrite dissent? Butler is interested in identity only as a "point of convergence" across differences (Gender Trouble 10), but she says little about either identity as socially revealed or what might compel solitary queers to come together to effect change, political or otherwise.

With the disappearance of homosexual identity under Butler's queer reign, the expression of homophobia is given a much freer rein since there would be, under a queer regime, no homosexual subjects to combat the homophobic subject (Bersani 56). However, Butler subtly admits that a concrete homosexuality might be at times yielded to if it can effect a queer collective contestation ("Critically Queer" 14). ${ }^{7}$ But she never states just what constitutes an effective body politic, or how one might assume with assurance that all its members will share the same (contesting) interests, or how individuals sustain over time the stimuli to fuel an ever-aware and always-ready queer critical reasoning.

These questions accentuate one of the main problems of much queer theory: if all identities are locally conferred, how can queer

${ }^{7}$ Although she never directly says 'homosexual communal politically-based identity,' Butler leaves that possibility open when she says that the term "queer," as a site of collective contestation, is "perhaps also yielded in favor of terms that do the political work more effectively" ("Critically Queer" 14). 
values develop or change when interaction among individuals at a level above the immediate is not thoroughly engaged or considered? Lisa Bower intriguingly argues that "we have seen the development of different types of political practice which invoke political identities that do not ask the law for recognition" (281). This supports a populist perception that individuals can effect change merely through dissidence, or by fuelling an inward-looking identity that is always different from. In other words, they hope to create change by simply being but not necessarily acting. A self-centered will-to-power cannot contest anything, especially as unwillingness to identify interests beyond mere contestation will result in dominant self-interest groups doing it for the queer individuals who desultorily contest.

Bower's hope for a more immediate address to political problems is laudable. Yet without apparent structures beyond the atomized self by which to express desired change, it is difficult to know what fruitful contestations of any kind queers might achieve, in theory or in practice. Rather than using material beings providing visibility, Bower instead provides a straw person of "marginalized communities," which somehow share a transparent interest in common values. For example, Bower prescribes that queers "use legal descriptions of homosexuality to create contestation in the public sphere, to re-imagine community and to transform the political field by challenging community members' own identifications" (283). The homosexual as a transgressive but community-identified force seems paradoxical and untenable; moreover, queering advocates the intensification of localized groups in their marginalities, to the point where larger group action becomes impossible. The result is that certain groups who see an opportunity to promote their own agenda or who seek dominance will fill any political vacuum.

It is strikingly naïve to imagine that dominant groups would take positive action to respond to the minority group assertions that claim that societies regularly enforce misrecognition of the violence wrought through heteronormativity. Bower suggests that a "renewal of community and politics may occur through a politics of direct address enacted through cultural interventions and the re-imagination of community" (283). Favoring the tactics of Queer Nation's mall kiss-ins, Bower imagines that direct address, as a form of populism, can effectively disrupt and alienate heteronormative structures so that resulting ruptures will lead to greater (re)creation and reconfiguration 
of minority social spheres. To elide identity politics, Bower proposes a strategically selective "role of identification" (285) wherein difference, conceived as value-neutral, cannot depend on one thing or another for its constitution. Therefore, homosexual identity (in a queer world), because it coheres everywhere (as part of the regime requiring its transgressive nature), really would cohere at no particular site (Savoy 150). Difference, as a somewhat abstract organizing concept - which, because it is queer, likely would not organize in a coherent fashion - presumes a largely invisible, apolitical, incoherent structure with no one (identity) in particular at its helm. Queer work, beyond dissidence, has no direction and insists upon not choosing one. Clearly, these kinds of proposals are antisocial in that there is no real constituency except for the selfregarding individual. Identity politics, though in some ways flawed, has at least the fundamentals of cross-social concern and identification working for it.

\section{Reviving the Social}

This queer politics, especially as it utilizes a deconstructive critique of identity, conceals subjectivity within a rhetoric of composite intersections. If constructed identity categories are unstable because of what they exclude, queer (anti-)identities are even less stable because of their multifaceted, porous natures. It would, of course, be too simple to say that queers want to do away with identity altogether, since people will invariably converge at some point, arbitrarily or otherwise. Rather, queers hope to open up identity categories as sites of contestation. The notion of strategic essentialism again arises, as Seidman observes that "the aim is not to abandon identity as a category of knowledge and politics but to render it permanently open and contestable as to its meaning and political role. In other words, decisions about identity categories become pragmatic, related to concerns of situational advantage, political gain, and conceptual utility" (“Introduction” 12).

But at these new sites, whose voices are heard and whose interests are pandered to? If queers struggle to abandon the baggage of binarized identity, for example, can one actually expect any subject to be available to speak for their positions? The problem is that queer theory, like much self-referential resistance theory, cannot support a position like Bower's politics of direct address; it is a theory that can- 
not constitute a workable politics since it is concerned foremost with individuals acting discretely. Difference between persons gives way to an examination of difference within a person without external referents. The queer goal is to call forth and contest the knowledge and social practices inherent in (self) identity and desire, but this sounds much like the isolated individual who becomes the creator of self, as the fount of an atomized and socially disengaged knowledge.

In ways similar to how paradoxical postmodernism predicates its existence on modernism, queer theory and practice seize upon identity as a necessity for its anti-identity project. However, again we see that queer practitioners, in their efforts to look ever more inward to understand the epistemologically bordered locus of self, begin to resemble the modernist artist who attempted to translate the world through his or her own mind. Although not quite that simplistic, queer theory nonetheless cannot argue the effects of and arousals caused by the trappings of power. The queer recreation of identities heretofore dismissed as constituting a rational, coherent, and normalizing category results in politically disinterested subjects whose only engrossments are revealed to be an encompassing selfinterest. Queer offers up the seductive right to dissent as individuals; there is no inducement to dissent collectively.

Yet to promote stability in order to pursue other noncontesting interests, the subject will resort to the structures that regulate activity for him or her, most notably, the law, among other social configurations. Vying for power - who has it, who can use it, to what end - needs to be reified and reinscribed in order to promote a force of stability that will allow time for subjects to be social. As Kirsch rightly asserts, when writing about how the involvement of individuals drives social action, these concerned subjects "need to have structural representation in order to maintain the energy needed for sustained opposition. Individuals working against their oppressors, whether in the workplace or neighborhood, cannot succeed without a mechanism that can play a larger role in incorporating them into communities of resistance where mutual recognition is present" (118). The internalized structures that are required in order for us to interact are also part of the environments in which we get to act, to mediate actions, to be social.

But social division, which seems to be the promise of a poststructuralist critique of identity, only promises more fragmentation 
under the aegis of the sign of the queer, resulting in only more isolation and doubt about the possibilities of communal action. The sanctioning of nonidentity becomes as regulatory as it presumably is under the current regimes of binarized norms. As the queer becomes increasingly theorized in the academy, fears are being expressed about the possibility of its homogenization. The totalizing effects of an omnipresent late-capitalist ideology, which sets up deviance only to co-opt it, would seem to be the likely suspect of this homogenizing maneuver. As Morton points out, "Queer Theory is now recognized as nothing but an ideological maneuver to enable the assimilation of queers to mainstream economic practices, which is to say, the assimilation of those on the sexual margins to the free market" ("Pataphysics" 5). Morton forcefully argues that material conditions, not a libidinalized economy, should be prioritized in order to bring about true liberation.

Morton compares the effects of the economic boom in the 1990s - what he calls "the Age of Difference" - with the long postwar economic expansion in the United States. In the 1950s to the 1970s, "the emphasis of Gay Liberation was on inclusion in the common economic resources of capitalist democracy in spite of differences, [whereas] in the Age of Difference, the emphasis of Queer Theory is on inclusion in global capitalist democratic rights to consumption tailored to differences" (14). Although I think Morton means to include consumerist-oriented gays and lesbians in that category of consumption, he nevertheless adroitly points out how the queer has been co-opted due to his or her lack of engagement in reimagining the social. Indeed, unless queer theory's 'niche' politics can prompt reconceptualizations in social spheres (wherein it must present itself as a desirable alternative in order to confront investments in current dominating structures), change wrought through a refiguring of the self as simply 'different' will remain only conceptual.

The question of how queer theory itself functions as a practice of differences arises when Michael Warner states that "people want to make theory queer" (Fear xxvi) ${ }^{8}$ One wonders how queer theory,

\footnotetext{
${ }^{8}$ The idea of queering everything is modified somewhat in Warner's recent work. Here he states that the new use of queer "does not simply replace or expand the ones [such as lesbian and gay]. It competes with them and, if taken literally, will rule out many of the people whom the revaluation of the term was meant to serve" (Publics 316).
} 
roaming within a deconstructed redefinition of a politics of difference(s), could even recognize itself, let alone other theories. Under the queer rubric that this, for example, is something that could not be anticipated (and thus not known), queering quickly becomes a theory of atomized differences traveling along intersecting structures that, altogether, cannot recognize strategic positions of contestation since such configurations (under a queer gaze) are without structural identification. Theory, in this instance, is strangely dislocated from its material subject, although queer theory, presumably willing to participate in its own critique, threatens itself with its own relegation to liminality. It is as though the scare quotes that once accompanied the word "queer" would, in an ironic reversal, return and extend the quotes to encompass not only scare-quoted "queer" but the word "theory" as well. As a tool signaling irony, such scare quotes serve as a counterpart to what might be the embodiment of a queer person: the scarecrow. Each signals an ironic existence, and neither cannot signal or be a material body.

It is also ironic that queer theory's double imperative - to maintain the integrity of critical distance while actively disturbing the foundation of the subject - works to undo itself, in theory and in practice. Such a disappearance can only be the result of an insistence on submission to a deconstructive taxonomy. However, it would be extremely naïve to think that this spells the end of queer theory. Although it may not maintain its own distinctive categorization, especially within the academy, its mission, as stated by Michael Warner, to queer all theory, is not unwelcome. Queer theory, despite its foundation in social constructionism, anti-identity formulations, and homosexual transgression, must still rely on the identification of 'the homosexual' and keep this category in visible circulation. But if it does not resolve the impasse created by its suspension or deferral of homosexual subjectivity and political strategies, queer theory will only continue to undermine its homosexual base by, as Savoy alleges, smuggling homophobia "in through the back door," thereby reinscribing a view of homosexuality as "highly dispensable" (134). Queers must stop disposing of the homosexual either through theoretical necessity or through (unintentional) social abnegation.

The resolve of this impasse seems to return us to Butler's call to a form of strategic use of identity categories or subject positions 
as warranted. However, just who will make that determination without resorting to forms of dominance is yet another paradox to overcome. There appears no emancipation eminent in the queer project beyond a studied self-examination that presumably frees the psyche and creates another version of 'the best possible you,' a concept ironically promoted as the promise of capitalism's modern advertising campaigns. As Kirsch wryly notes, "queer theory's highlighting of the impossibility of identity and the relativity of experience closely follows the development of current capitalist relations of production, where the self-contained individual is central to the economic goal of creating profit through production and its by-product, consuming" (17-18). He adds, echoing Morton, that the tenets of queer theory do not resist the capitalist production of equality but have paradoxically mirrored it.

Rather than come to terms with the efficacy inherent in expansive and corrective forms of sexual identity politics, queers have simply been recuperated by the forces of consumerist production. Queer theory has initiated a politics of irresolution while focusing on its ironic "disciplining compulsory imperative to remain undifferentiated" (Seidman, "Identity" 133). It appears unable to recognize that political disinterest is a liability and prey to conservative political recuperation. The additional inability of queer theory to react quickly or in any substantive way to immediate needs is another pitfall. The necessary risk of a 'pure' queer project cannot be undertaken without reestablishing and reaffirming its roots in the visible communities from which it arises and to which it must answer.

I thank Robert K. Martin and Lianne Moyes for their comments on an earlier draft of this paper.

\section{Works Cited}

Bersani, Leo. Homos. Cambridge MA: Harvard University Press, 1995.

Bower, Lisa. “Queer Problems/Straight Solutions.” Phelan 267-91.

Butler, Judith. Bodies That Matter: On the Discursive Limits of "Sex." New York: Routledge, 1993.

. Gender Trouble: Feminism and the Subversion of Identity. New York: Routledge, 1990.

_. "Critically Queer." Phelan 11-30. 
Cooper, Dennis. "Johnny Noxema to the Gay Community: 'You are the Enemy." The Village Voice 30 Jun. 1992: 31-33.

Dong, Arthur, dir. Licensed to Kill. Deep Focus Productions, 1997.

Edelman, Lee. Homographesis: Essays in Gay Literary and Cultural Theory. New York, Routledge, 1994.

Fuss, Diana. Essentially Speaking : Feminism, Nature \& Difference. New York: Routledge, 1989.

Halperin, David M. "How to Do the History of Male Homosexuality." GLQ 6 (2000): 87-123.

Kirsch, Max H. Queer Theory and Social Change. New York: Routledge, 2000.

Martin, Robert K. Closing plenary. Sex on the Edge Conference. Concordia University, Montreal. 11 Oct. 1998.

Morton, Donald. "Changing the Terms: (Virtual) Desire and (Actual) Reality." The Material Queer: A LesBiGay Cultural Studies Reader. Ed. Donald Morton. Boulder: Westview, 1996. 1-37.

- "Pataphysics of the Closet." Marxism, Queer Theory, Gender. Eds. Mas'ud Zavarzadeh, Teresa Ebert, Donald Morton. Syracuse: Red Factory, 2001. 1-70.

Phelan, Shane, ed. Playing with Fire: Queer Politics, Queer Theories. New York: Routledge, 1997.

Savoy, Eric. "You Can't Go Homo Again: Queer Theory and the Foreclosure of Gay Studies." English Studies in Canada 20 (1994): 129-52.

Sedgwick, Eve Kosofsky. Epistemology of the Closet. Berkeley: University of California Press, 1990.

- "Gender Criticism." Redrawing the Boundaries: The Transformation of English and American Literary Studies. Eds. Stephen Greenblatt and Giles Gunn. New York: MLA, 1992. 271-302.

Seidman, Steven. "Identity and Politics in a 'Postmodern' Gay Culture: Some Historical and Conceptual Notes." Warner, Fear 105-42.

- "Deconstructing Queer Theory or the Under-theorization of the Social and the Ethical." Social Postmodernism: Beyond Identity Politics. Eds. Linda Nicholson and Steven Seidman. Cambridge MA: Cambridge University Press, 1995. 116-41.

- . "Introduction." Queer Theory/Sociology. Ed. Steven Seidman. Cambridge MA: Blackwell, 1996. 1-29 
84 / Lesk

Turner, William B. A Genealogy of Queer Theory. Philadelphia: Temple University Press, 2000.

Van Leer, David. "The Beast of the Closet: Homosociality and the Pathology of Manhood." Critical Inquiry 15 (1989): 587-605.

Warner, Michael. "Introduction." Warner, Fear vii-xxxi.

- ed. Fear of a Queer Planet: Queer Politics and Social Theory. Minneapolis: University of Minnesota Press, 1993.

- Publics and Counterpublics. New York: Zone, 2002.

Warner, Tom. Never Going Back: A History of Queer Activism in Canada. Toronto: University of Toronto Press, 2002. 